\author{
Marta TrębaczewsKa \\ Wydziat NaUk SPOEECZNYCH \\ Wyższa SzkoŁa Pedagogiczna im. J. Korczaka w Warszawie \\ E-MAIL: MARTA.TREBACZEWSKA@GMAIL.COM
}

\title{
KIEDY OWU NIE MA, ŻOŁNIERZYKI SĄ LENIWE, BETA NISKA, A MARZENIE O FASOLCE NIESPEŁNIONE... WPŁYW NIEPŁODNOŚCI NA RELACJE MIĘDZY PARTNERAMI
}

Nieplanowana bezdzietność, czy też wtórna niemożność ponownego rodzicielstwa są dziś poważnym, bo dotyczącym (według różnych statystyk) od miliona do trzech milionów par w Polsce - problemem społecznym. Niepłodność to nie tylko niemożność posiadania potomstwa, ale też cały zespół czynników wpływających na społeczne funkcjonowanie osób nią dotkniętych. Wpływa na sytuację materialną, zawodową i towarzyską, ale przede wszystkim zmienia relacje wewnątrzrodzinne. Uciążliwe i długotrwałe terapie wymagają przedefiniowania relacji między partnerami oraz przekraczania wielu granic - intymności (zarówno intymności rozumianej wyłącznie jako cielesność, jak i intymności choroby), wytrzymałości (zarówno fizycznej, jak i emocjonalnej), czy zaufania. Wymusza to redefinicję relacji małżeńskich/ partnerskich - są wypracowywane nowe zasady życia rodzinnego (i społecznego) podporządkowanego (lub nie) wspólnemu (lub nie) celowi. Ciała partnerów przestają być ich wyłączną własnością i zaczynają przybierać formę użytkową, mającą do spełnienia funkcję reprodukcyjną. Zmienia się sposób posługiwania ciałem i obchodzenia się z nim, w postrzeganiu siebie następuje wyraźny rozdział na umysł i ciało poddawane terapiom, tworzony jest nowy język pozwalający komunikować o swoim ciele i jego elementach w sposób akceptowalny dla partnerów oraz pozwalający na swoiste „zaprzyjaźnienie się" z problemem (na przykład infantylizacja języka - śnieżynki jako zamrożone zarodki, czy żołnierzyki jako plemniki).

Celem artykułu jest zarysowanie problemów życia codziennego partnerów/ małżonków długotrwale starających się o potomstwo. Dotychczasowe, medialne ujęcie tematu, sprowadza ten problem do politycznych dyskusji o zapłodnieniu in vitro, zupełnie pomijając fakt psychicznego, społecznego i egzystencjalnego lęku, który codziennie towarzyszący niepłodnym parom i zmienia ich 
wzajemne relacje. Temat zobrazują wstępne wyniki badań jakościowych prowadzonych od 2010 roku wśród par walczących z niepłodnością.

Pomimo licznych doniesień o upadku tradycyjnego modelu rodziny i związku na rzecz tych nienormatywnych (homoseksualne, DINK, LAT, single) wydaje się, że chęć długotrwałej, monogamicznej relacji heteroseksualnej, której dopełnieniem jest potomstwo - ma się całkiem dobrze, czego dowodem jest wzrastająca liczba urodzeń [GUS: 2013]. Niestety, około 15\% par w wieku rozrodczym, a więc ok. $3 \mathrm{mln}$ osób [Pawelec, Pabian 2012], ma istotny problem z realizacją swych zamierzeń prokreacyjnych ze względu na niepłodność jednego lub obojga partnerów. Warto w tym miejscu wspomnieć, że niepłodność jest stanem odwracalnym i określenia tego nie można używać zamiennie ze słowem „bezpłodność”, która z kolei oznacza trwałą niezdolność do poczęcia dziecka, na przykład na skutek wady wrodzonej (brak obu jąder u mężczyzny, brak jajników u kobiety). Dodatkowo, ze względu na okres trwania niepłodności wyróżnia się niepłodność pierwotną oraz niepłodność wtórną, gdzie niepłodność pierwotna (sterilitas primaria) oznacza, że kobieta nie może zajść w ciążę mimo regularnego współżycia $\mathrm{z}$ partnerem bez stosowania środków antykoncepcyjnych od ponad roku. Niepłodność wtórna (sterilitas secundaria) dotyczy zaś takich przypadków, w których przynajmniej raz zaistniała ciąża (niezależnie od tego, czy doszło do poronienia, porodu czy ciąży pozamacicznej), a następnie minęły dwa lata bez zajścia w ciążę, mimo regularnie odbywających się stosunków płciowych. Rozróżnia się też niepłodność wrodzoną (sterilitas congenita) oraz niepłodność nabytą (sterilitas acquisita), [Bidzan, 2010].

Ponadto, należy zwrócić uwagę na fakt, iż o niepłodności mówimy zawsze w odniesieniu do obojga partnerów (niepłodność małżeńska), niezależnie od strony, po której leży przyczyna - tym bardziej, że niepłodność nie jest, jak się powszechnie uważa, problemem leżącym po stronie kobiety. Najnowsze dane mówią, że po stronie kobiety leży 35\% przyczyn niepłodności, kolejne 35\% po stronie mężczyzny, ok. 25\% dotyczy obojga małżonków, a 5\% stanowią przyczyny nieznane [Gąsiorowska, 2005: 53]. Niepłodność z przyczyn nieznanych to niepłodność idiopatyczna, szacowana jest niekiedy na 10-20\% par (w zależności od ilości wykonywanych badań, przyjętych norm i interpretacji - to niemożność posiadania przez parę potomstwa przy braku jakichkolwiek nieprawidłowości w podstawowych badaniach diagnostycznych [Szamatowicz 2008].

Kwestią „winy” partnerów i jej wpływu na związek zajmują się szeroko głównie psychologowie i psychoterapeuci wskazując często, że niepłodność definiowana jako niemożność posiadania potomstwa pomimo regularnych (3-4 razy w tygodniu) stosunków seksualnych bez zabezpieczeń w ciągu 12 miesięcy, silne związki umacnia jeszcze bardziej, a słabe jeszcze bardziej osłabia. Socjo- 
logiczne analizy podają te twierdzenia w wątpliwość - na przykład I. Przybył w podsumowaniu swoich badań napisał:

Analiza literatury przedmiotu poddaje w wątpliwość tezę, że niepłodność ma psychologiczne konsekwencje dla wszystkich małżeństw. Nie ma dotychczas dokładnego rozpoznania, na ile niepłodność wzmaga objawy psychopatologiczne partnerów, odnawia dawne problemy małżeńskie lub wywołuje nowe, a także jakie czynniki są odpowiedzialne za to, że tylko niektóre małżeństwa z powodzeniem znoszą stres związany z niepłodnością. (...)W świetle dotychczasowej wiedzy można stwierdzić, że niepłodność ma silny wpływ na emocjonalne i seksualne życie małżonków. Małżonkowie niepłodni często czują się izolowani, doświadczają silnych negatywnych emocji - lęku i depresji, mają poczucie winy i wstydu, niższej wartości. Nie ma jednak dotychczas dokładnego rozpoznania, na ile niepłodność wywołuje nowe problemy małżeńskie, a także jakie czynniki są odpowiedzialne za to, że tylko niektóre małżeństwa z powodzeniem znoszą stres niepłodności. Stwierdzono natomiast, że czynnikami, które w zróżnicowany sposób wpływają na związek małżeński w tym zakresie są nasilenie potrzeby rodzicielstwa oraz identyfikacja płciowa partnerów. [Przybył 2002: 246-248]

Niniejszy tekst nie będzie skupiał się na ocenie relacji partnerskich w związkach dotkniętych niepłodnością. Ponieważ złożoność tematu nie pozwala na jego kompleksowe potraktowanie, celem tekstu jest próba socjologiczno- antropologicznej analizy zmian, jakie zachodzą w tych relacjach pod wpływem diagnozy i leczenia na różnych jego etapach - z zastrzeżeniem, iż całkowita separacja od spostrzeżeń natury psychologicznej jest w tym temacie niemożliwa.

Badaniu metodą indywidualnych przypadków (2011-2013) poddano 22 osoby (11 par). Zastosowano technikę swobodnego wywiadu pogłębionego. Wywiady były przeprowadzane indywidualnie z każdą z osób, w 6 przypadkach (3 pary) do wywiadu wykorzystano komunikator internetowy. Rekrutacja respondentów odbywała się głównie poprzez portal www.nasz-bocian.pl i forum gazeta.pl oraz w wyniku bezpośrednich kontaktów z pacjentami warszawskiej kliniki leczenia niepłodności (NOVUM). Jednym z głównych kryteriów doboru respondentów był staż w staraniach o potomstwo. Po zapoznaniu się z literaturą przedmiotu przyjęto, iż staż ten powinien wynosić co najmniej 3 lata - na okres pierwszych trzech lat przypada bowiem czas zintensyfikowanych starań uznany za „normalny”, a więc niebudzący podejrzeń (12-18 miesięcy), oraz czas badań wstępnych, nieprzesądzających o jednoznacznej diagnozie. (W przeprowadzonym badaniu tylko jedna para (P7) miała świadomość swojej niepłodności przed zawarciem związku małżeńskiego. 
Ja wiedziałem od początku, prawie jak tylko zaczęliśmy się spotykać, że dziecka normalną drogą to my mieć nie będziemy, bo J. ma jakieś problemy. Ale byliśmy bardzo młodzi i bardzo zakochani, więc nie uważałem, że w tamtej chwili to jest takie istotne. Zresztą o dziecku na serio zaczęliśmy rozmawiać długo po ślubie. 3, czy 4 lata.

Tabela 1. Respondenci

\begin{tabular}{|c|c|c|c|c|c|c|c|c|c|c|c|c|}
\hline \multirow[t]{2}{*}{ L.P. } & \multirow[t]{2}{*}{$\begin{array}{c}\text { Staż } \\
\text { związku } \\
\text { (deklara- } \\
\text { cje respon- } \\
\text { dentów) }\end{array}$} & \multirow[t]{2}{*}{$\begin{array}{l}\text { Lata } \\
\text { starań }\end{array}$} & \multicolumn{2}{|c|}{ Wiek } & \multicolumn{4}{|c|}{ Wykształcenie } & \multicolumn{4}{|c|}{ Przyczyna niepłodności } \\
\hline & & & $\mathrm{k}$ & m & & & r & & $\mathbf{k}$ & $\mathrm{m}$ & $\mathrm{k} \mathrm{i} \mathrm{m}$ & $\mathrm{i}$ \\
\hline P1 & 6 & 3 & 31 & 31 & $s$ & & & $\mathrm{w}$ & & & + & \\
\hline P2 & 4 & 3 & 27 & 35 & $\mathrm{~s}$ & & & $\mathrm{w}$ & & + & & \\
\hline P3 & 8 & 3 & 33 & 32 & & $\mathrm{w}$ & & $\mathrm{w}$ & & & & + \\
\hline $\mathrm{P} 4$ & 6 & 4 & 34 & 36 & & $\mathrm{w}$ & $\mathrm{s}$ & & + & & & \\
\hline P5 & 5 & 4 & 37 & 44 & $s$ & & $\mathrm{~s}$ & & & + & & \\
\hline P6 & 7 & 5 & 30 & 33 & $s$ & & & $\mathrm{w}$ & + & & & \\
\hline P7 & 9 & 5 & 38 & 39 & $\mathrm{~s}$ & & $\mathrm{~s}$ & & + & & & \\
\hline P8 & 10 & 6 & 38 & 41 & & $\mathrm{w}$ & $\mathrm{s}$ & & & + & & \\
\hline P9 & 9 & 7 & 36 & 37 & & $\mathrm{w}$ & & $\mathrm{w}$ & & & + & \\
\hline P10 & 14 & 9 & 40 & 40 & $\mathrm{~s}$ & & & $\mathrm{w}$ & + & & & \\
\hline P11 & 15 & 14 & 41 & 43 & & $\mathrm{w}$ & & $\mathrm{w}$ & & + & & \\
\hline & & & & & 6 & 5 & 4 & 7 & $36,36 \%$ & $36,36 \%$ & $18,18 \%$ & $9,09 \%$ \\
\hline 11 & & & & & 1 & & 1 & & & 99,9 & & \\
\hline
\end{tabular}

Dla uzupełnienia obrazu posłużono się analizą najczęściej odwiedzanych forów internetowych poświęconych problematyce niepłodności oraz wykorzystano komentarze czytelników publikowanych w internecie artykułów dotyczących problemu. 
Z przeprowadzonych badań wynika, iż staż w staraniach o dziecko nie ma istotnego wpływu na obszary, w jakich zauważalne są zmiany w relacjach pomiędzy starającymi się partnerami. Długość starań związana jest jedynie z ich intensyfikacją lub osłabieniem w miarę upływu czasu. Dla przykładu: strach niemogącej zajść w ciążę partnerki przed znalezieniem sobie innej - płodnej - przez partnera towarzyszy tak samo dwudziestosiedmiolatce z trzyletnim stażem starań, jak i czterdziestolatce po 14 latach nieudanych prób. Jednak strach ten jest silniej artykułowany przez drugą kobietę, która dotkliwiej odczułaby odrzucenie i samotność:

(P10, K): Oczywiście, że o tym myślę i P. wie, że spać przez to czasem nie mogę. On ma tylko 40 lat, ja aż 40. Ja już praktycznie nie mam szans, a on ma ciągle mnóstwo możliwości naokoło. Gdyby ode mnie odszedł, to ja zostaję sama, do końca życia. Żadnych dzieci na starość, a kto będzie chciał się związać z rozwódką po 40, z którą coś nie tak? P. mówi, że nigdy mnie nie zostawi, i ja mu w większości wierzę. Tylko czasem się budzę zlana zimnym potem. Że puka mi ktoś do drzwi, ja otwieram, a tam gówniara $z$ dzieckiem na ręku mówi, że to mojego męża. Że poznali się na wyjeździe służbowym. P. się śmieje, ale to wcale nie jest śmieszne.

Podobnie jest w sytuacji odwrotnej - zarówno mężczyzna tuż po 30 roku życia, jak i tuż po 40 roku życia obawiają się odejścia partnerek, ale u młodszego mężczyzny strach jest niwelowany wiarą w naukę i jej rosnące możliwości:

(P1, M): Mam jeszcze trochę czasu. Medycyna rozwija się szybko, za parę lat dzisiejsze problemy nie będą żadnymi problemami. Na razie cieszymy się sobą, że jesteśmy w tym razem. A. mnie nigdy nie piętnuje.(...) No pewnie, że się boję, że się to może kiedyś zmienić. Ale na razie nie uprawiam czarnowidztwa, że znajdzie lepszy model.

W wypowiedzi 41-latka natomiast strach przed odejściem partnerki jest potęgowany brakiem wiary w swą męskość:

(P8, M): Proszę mnie źle nie zrozumieć, co to to nie, żona nigdy, podkreślam: nigdy, nie dała mi odczuć, że jestem jakoś wybrakowany. Żona jest bardzo spokojną i wyważoną osobą, nigdy nie zrobiłaby niczego, nie powiedziałaby czegoś, bo słów już nie można cofnąć i oboje o tym wiemy. Także nie, z jej strony nigdy nie czułem się gorszy. Sam ze swojej się czuję. I cholernie się boję, że jej tego spokoju zabraknie, że..., no..., że pójdzie z kimś kto ją zapłodni, mówiąc brzydko. $Z$ drugiej strony się nie będę dziwił, tak? Ja, wie Pani, nigdy nie byłem sam w życiu. Miałem rodziców, trójkę rodzeństwa, później żona, zawsze ktoś obok. 
Etapy walki z niepłodnością nie różnią się od etapów, jakie przechodzi każdy człowiek dotknięty ciężką chorobą. Pawelec stwierdza, że „Niepłodność to wielki dramat pary. Stan psychiczny osób, które nie mogą mieć dzieci jest porównywalny do tego, co przeżywają osoby chorujące na nowotwory czy ciężkie schorzenia kardiologiczne, zatem skala emocji, które pojawiają się u takich par jest ogromna" [Wysocki 2013].

Mamy więc w niej do czynienia z:

1. Zaprzeczeniem i negacją.

2. Buntem i gniewem.

3. Pertraktowaniem i negocjacjami.

4. Depresją.

5. Pogodzeniem się z losem [E. Kübler-Ross 1998].

Różnica polega jedynie na tym, że w przypadku niepłodności etapy te przechodzą oboje partnerzy, bo niepłodność należy zawsze rozpatrywać w odniesieniu do pary - niezależnie od tego, czy definitywna przyczyna niepłodności odnosi się do jednego z partnerów.

Prawdopodobieństwo znajdowania się pary na ostatnim etapie jest większe w przypadku par z dłuższym stażem leczenia, jednak badania wskazują, że fakt pozostawania na określonym etapie jest raczej skorelowany z osobowością i charakterem partnerów, niż z czasem, jakim są parą (choć jednoznaczna opinia należy w tej kwestii do psychologów). Przykładowo, pesymiści, osoby o niskiej samoocenie, nieufne mają tendencje do szybszego poddawania się i szukania rozwiązań zastępczych (adopcja, adopcja prenatalna, surogactwo). Przez poszczególne etapy szybciej zdają się przechodzić także osoby nastawione na działanie i szybki efekt. Z kolei u par, gdzie przynajmniej jeden z partnerów jest silnym optymistą, dochodzenie do poszczególnych etapów zajmuje więcej czasu, ponieważ comiesięcznego rozczarowania nie traktuje się w kategoriach żałoby po stracie, ale raczej jako motywację do dalszych starań. Warto również dodać, że w badaniach wzięły udział pary, które etap zaprzeczenia diagnozie i negacji problemu - przynajmniej w sferze deklaratywnej - mają za sobą, skoro zdecydowały się na leczenie.

Analizując relacje partnerów niepłodnych można stwierdzić, iż zmiany w nich zachodzące dotyczą realizacji właściwie każdej (instytucjonalnej i osobowej) funkcji rodziny. Korelacje pomiędzy nimi są jednak tak silne, że trudno jest zastosować jednoznaczną gradację. Nie można przecież odseparować relacji seksualnej od prokreacyjnej, emocjonalnej, czy opiekuńczej, bo są one ze sobą ściśle powiązane. W niniejszym artykule skupię się jednak tylko na 
dwóch aspektach relacji partnerów niepłodnych, które uważam za najbardziej wyraziste.

Pierwszy obszar zmian inicjujący szereg dalszych, to sfera ekonomiczna.

Większość badanych (18 osób, $10 \mathrm{~K}, 8 \mathrm{M}$ ) zwróciło w badaniu uwagę na fakt swoistej „niesprawiedliwości” w leczeniu niepłodności. Wynika ona ze specyfiki problemu, który - niezależnie od przyczyny - w znakomitej większości przypadków „leczony” jest przez kobietę, która ma być w ciąży.

(P5, K) Widzi Pani, tak to jakoś jest poukładane, że zawsze pod górę. U mnie w rodzinie kobiety płodne jak króliczki - mama urodziła nas troje, sama miała dużo rodzeństwa, bo pięcioro. No takie czasy były. Siostra ma też trójkę, brat bliźniaczki. Ja wiem, że mogłabym mieć dzieci z kimś innym, ale ja nie chcę z kimś innym, rozumie Pani? Chciałabym powiedzieć, ze to wina teściowej, bo mąż jak był mały, to go siup! Do przedszkola na 8 godzin. A to, proszę Pani, nie były takie klubiki maluszka jak teraz. No i on stamtąd przywlekał różne choroby, a w tym i świnkę. No więc żołnierzyki u nas są leniwe i jest ich mało i nie bardzo waleczne. A jak się już uda jakiegoś przechwycić, to wtedy ja na stół i jazda: tu kłują, tam szprycują, a jeszcze wcześniej hormony i hormony i hormony. I przetykanie, żeby żołnierzykom było łatwiej i to i tamto, co tam będę w szczegóły wchodzić, pani Pewnie wie. Chodzi mi o to, że jakby nie było, to i tak na końcu zawsze ja leżę na stole. A mąż musi się zdrowo odżywiać, dużo spacerować i nosić bawełniane spodnie. Tak w dużym uproszczeniu, żeby Pani zrozumiała, o co mi chodzi.

(P2, M) Ja się niedobrze z tym czuję. Jestem starszy, bardziej doświadczony i w końcu jestem facetem i to ja powinienem wszystko znosić. A tymczasem ja tylko stoję i patrzę, jak K. faszerują jak gęsi na pasztet. Zresztą przeważnie pasztet na razie z tego wychodzi. Moi faceci są mało ruchliwi, więc trzeba im wszystko ułatwiać. Nie chcę być ordynarny, ale w skrócie to jest tak, że ja biorę filmik, czy gazetkę, idę za kotarkę, 5 minut i po sprawie. To K. musi się przygotowywać, to K. jest tym workiem treningowym.

Leczenie niepłodności partnerów jest faktycznie bardziej obciążające dla kobiety. Stwierdzenie to nie odbiera mężczyznom prawa do przeżywania sytuacji, czego dowodem może być wypowiedź kobiety prowadzącej blog www.4krokidocudu.pl:

Dodatkowo mężowi ciężko było zrozumieć i zaakceptować fakt pewnej niesprawiedliwości - że to on ma być silnym ramieniem i że od momentu podjęcia leczenia, to na moich uczuciach i nastrojach będziemy się skupiać. Dodatkowo Piotr musiał nauczyć się wyłączać w trudnych chwilach (mój płacz, rozdrażnienie, podłe samopoczucie) typowe dla mężczyzn myślenie w kategoriach „znajdźmy rozwiązanie, sposób na polepszenie nastroju”. Tu nie ma sposobu - to po prostu musi 
minąć a jedyne co mężczyzna może zrobić to: przytulić, wysłuchać, nie doradzać i negować..."

Nierzadko zdarza się, że pierwsze lata starań związane są z codziennymi wizytami w przychodni, przyjmowaniem hormonów zmieniających nastrój, wymuszają całkowite podporządkowanie się procedurom (np. leżenie po zabiegach inseminacyjnych). Skutkiem takiej sytuacji jest istotna zmiana w życiu zawodowym kobiet. Wykonywanie wielu zawodów jest bowiem ograniczone lub wręcz niemożliwe.

(P4, K) Pewnie Pani powie, że to ironia losu. Ja też tak mówię, że los jest przewrotny, złośliwy. Bo ja jestem z wykształcenia przedszkolanką. Pracowałam w przedszkolu jeszcze na studiach i tak zostało. A teraz sama nie mogę mieć dzieci. Jak się dowiedzieliśmy na $100 \%$, to od razu chciałam się leczyć, bez żadnych tam powtarzań diagnozy w innych klinikach, bo może gdzie indziej wyjdzie inaczej. Ja mam PCOS [zespół policystycznych jajników - dop. M.T.]. Jak mnie zaczęli faszerować lekami, to nie wiedziałam, jak się nazywam. Tu antyandrogenów, tu antykoncepcyjne... Powiem Pani tyle: mąż i siostra byli w stanie ze mną przebywać. Nie mogłam tak chodzić do pracy, no bo jak, na dzieci miałabym krzyczeć? Zrezygnowałam.(...) Ciężko o tym mówić..., ale tak jest, że jestem teraz całkowicie zależna od męża. Z pensji przedszkolanki nie udało mi się nic odłożyć (śmiech). Mąż ma własną działalność, trochę mu pomagam. Chociaż żona ze mnie żadna, tak naprawdę - nie pracuje, $z$ dziećmi nie siedzi, gotować nie potrafi. Chociaż to akurat się zmieniło, bo się nauczyłam (śmiech). Ale na poważnie. Mam takie poczucie, że jak chciałabym krzyczeć, to nie do końca mogę.

Na zmianę w relacji ekonomicznej wskazują też mężczyźni:

(P9, M). Oboje mieliśmy takie same poglądy na życie: klasycznie, studia i dobra praca, podróże, użyć życia, a potem dzieci. Żeby mieć co im opowiadać. Trzy pierwsze elementy udało się zrealizować, oboje zawsze dobrze zarabialiśmy. W najlepszym okresie mieliśmy 15 tys. miesięcznie wspólnie, bez kredytu, bo mieszkanie jest po dziadkach. Także wystarczało nam na wiele. Nagle małżonka musiała zrezygnować z pracy. Każdy zabieg ją wykańczał fizycznie i psychicznie. Najpierw brała zwolnienia, później pracodawca się z nią pożegnał za porozumieniem stron. Czyli teraz mamy o połowę mniej. Czyli oprócz tego, że staramy się o dziecko, to jeszcze staramy się na to zarobić. Z małżonką rozmawiam o tym, wiem, że to dla niej podwójnie trudne. Nie może się pogodzić z utratą finansowej niezależności i wcale się jej nie dziwę. (...) Myślę, że nie daję jej odczuć, że jest ode mnie zależna, nigdy niczego takiego nie powiedziałem. Ale ona powiedziała, że jakbym ją zostawił, to ona ląduje na ulicy dosłownie z niczym. No to raczej też nie pomaga. 
Trzyletni program rządowy dla niepłodnych par gwarantuje refundację zabiegu in vitro dopiero od 1 lipca 2013 roku. Obejmuje pokrycie kosztów związanych z częścią kliniczną, jak i biotechnologiczną przy maksymalnie trzech próbach. To jedynie niewielka pomoc finansowa w leczeniu. Tymczasowa regulacja zapłodnień in vitro nie załatwia jednak palących problemów codziennej egzystencji - dni wolnych od pracy na potrzeby badań, zwolnień na czas burzy hormonalnej. W przypadkach, kiedy za problem z niepłodnością odpowiada oboje małżonków, może zdarzyć się, że w tym samym czasie żadne z nich nie może podjąć pracy, co skutkuje znacznym pogorszeniem ich stanu finansowego. W ten sposób tworzy się zamknięte koło: stres uznany za jeden z blokerów zajścia w ciążę jest potęgowany przez niepewną sytuacją finansową, konieczność zapożyczania się u rodziny (często związaną z kłamstwem na temat powodu dodatkowo wzmagającym stres), branie kredytów, co może uniemożliwiać uczestnictwo w dalszych procedurach medycznych i tym samym oddalać od posiadania wyczekanego potomstwa.

(P9, K) U mojego trzeba było operować żylaki powrózka [chodzi o operację żylaków powrózka nasiennego, która pozwala na bardziej precyzyjne uwidocznienie naczyń limfatycznych i tętnic jądrowych - dop. M.T.]. U mnie w tym samym czasie mniej więcej było leczenie hormonami zbijającymi prolaktynę, szykowałam się na udrożnianie jajowodów. Dwoje chorych w domu, jedno leży i kwiczy, drugie łazi po ścianach i wyje. I jak Pani myśli, da się pracować? Trochę mieliśmy odłożone, sprzedaliśmy jeden samochód... Jak bym chciała Pani policzyć koszty, to... Tylko się cieszę, że nas jakoś tam stać na to leczenie. Siostra się śmieje, że jak już nam się wreszcie uda, to nie będziemy mieli z czego dziecka utrzymać. Chyba nie muszę mówić, że chciałabym mieć taki problem?

Wizja wydatków, jakie trzeba ponieść jest również przyczyną odraczania leczenia na czas uzbierania potrzebnej kwoty. Okres ten może być trudny dla partnerów odmawiających sobie przyjemności dnia codziennego, co potwierdzają wypowiedzi forumowiczów (zachowano oryginalną pisownie postów):

zoselin 1987 10.04.12, 15:09 „Szczerze mowiac przeraza mnie mysl o kosztach. Co prawda przede mna dopiero cala ta droga w walce o dziecko,ale chcialam sie zorientowac co i jak. A moze akura inseminacja zakonczy sie sukcesem.... na razie zbieramy pieniazki i zaczynamy za jakies pol roku, gora rok."

mulan44 05-09-2011 21:17 „maskara i tyle. Mam odłożone dopiero 4 tys, chce zaczac w paździeniku. Może jeszcze coś oszczędzeale trzeba by sobie wszystkiego odmawiać. ja przez jakiś czas miałam szczęście leczyć się na nfz u fajnego endokrynologa, więc wiem w czym „tkwi diabeł”, ale i tak poszło na dojazdy ok 2000 ;/ ja teraz lecze zęby, wymieniam plomby, bo chciałabym mieć 
zdrowe gdy to się zacznie. Więc dorzucam te koszty do puli. Masakra, wszytsko się zbiera i zbiera i zbiera.

Venilia 05-11-2011 18:22 Z kasą jest bardzo ciężko, u nas przynajmniej. Kredyt na mieszkanie (notabene małe) sam się nie spłaci, dlatego na leczenie odkładamy każdy grosz, nie dla mnie ciuszki i głupotki - kupuje co trzeba bo mam priorytet teraz.I chcemy się obejść bez kredytu na ten cel tak długo jak się da.

$\mathrm{Na}$ koszty poniesione na leczenie składają się nie tylko elementy stricte medyczne. Do nich doliczyć bowiem należy na przykład koszty podróży do odległej od miejsca zamieszkania kliniki, zakwaterowania w miejscu leczenia, koszty związane ze zmianą trybu życia na zdrowszy, a więc odżywianiem się, dbaniem o kondycję fizyczną, czy należyty wypoczynek (np. ekologiczna i wysokogatunkowa żywność, suplementy diety, siłownia/ basen, profesjonalne masaże).

malwina 178 09.04.12, 20:55 Ja z dojazdami do Gdańska (mieszkam 200 km od tego miasta) wydałam ponad 20 tyś. Same badania, leki i wizyty to koszt około 10 tyś. Do tego dochodzi opłata programu - w moim przypadku zaryzykowałam i podeszłam do programu In vitro standard - którego koszt to rzekomo 5100 (najtańszy). Rzekomo, dlatego że do tego należy doliczyć („oczywiście nie koniecznie, ale było by to wskazane") koszt mrożenia zarodków, narkozy itdłącznie około 5 tyś. W moim przypadku organizm nie zareagował na leki zbyt szybko więc dłuższy czas byłam stymulowana. A to wiąże się z dodatkowymi kosztami za leki - każda wizyta kosztowała mnie około 1500 złotych (z lekami). Pieniądze z konta uciekały nie wiadomo kiedy... Ale dziś wiem ze to nie ważne - ważne są efekty - udało się za pierwszym razem - jutro idę posłuchać bicia serduszka mojego maleństwa (albo maleństw).

Martellina 05-09-2011 19.30 ja już nie zliczę ile wydaliśmy,jesteśmy po 5iui,które każda kosztowała ok.1500zł,jeden protokół ivf ok13000zł i crio ok2000zł,ale oprócz tego było jeszcze wcześniejsze leczenie u mojego zwykłego gina i badania,pewnie wyszłoby z 35000 tyś, ale to tak w przyblizeniu,bo nie pamietam wszystkich kwot,a przecież jest tego trochę.

Badani i forumowicze wskazują również na koszty związane z uatrakcyjnianiem pożycia seksualnego aby uniknąć „seksu pt. robimy dziecko”, na który składa się na przykład zakup bielizny.

Olalola 13-03-2012, 18.32 „Nie zapominajmy, ze przytulanie też kosztuje. Mój m miał dość rozkazów, ze to dzisiaj, nawet się zaczął wykręcać bólem głowy :D:D:D. Raz kupiłam seksi wdzianko, innym razem jeszcze bardziej seksi :) Myślałam, ze nawet jak nic by z tego nie wyszło, to chociaż przytulanko było atrakcyjne, a nie że ani to ani to $(-)$. Jeszcze dobre winko (czerone oczywiście, 
bo wpływa na ukrwienie macicy), wcześniej kolacja, film trochę erotyczy :; Aha, od witamin włosy i cera mi się poprawiły więc ogólnie, imo, warto w to inwestować niezależnie od wyniku"

Dodatkowym kosztem bywają także wyjazdy na urlop zalecane przez samych lekarzy jako środek wspomagający i ułatwiający poczęcie.

Jedna badana para zdecydowała się zainwestować także w całkowity remont mieszkania zgodnie z regułami feng shui, aby uczynić codzienne środowisko bardziej przyjaznym potencjalnemu poczęciu:

(P2, M) K. wyczytała gdzieś, że możemy mieć w mieszkaniu złą energię, bo meble źle stoją. Kolor ścian też był nie ten. I tak od jednego do drugiego na remont wydaliśmy już z 10 tysięcy.(...) Podoba mi się. Ale wtedy też mi się podobało. (...). A Pani jak myślii Bo mi jakoś trudno uwierzyć, że od przestawionego łóżka w drugą stronę ludzie szybciej zachodzą w ciążę. Przeszkadzać pewnie nie przeszkadza. (...) Może te pieniądze nie będą nam później potrzebne, jesteśmy na początku, może zaraz się uda. Powiem Pani za rok, czy to pomogło.

Zmiany w życiu zawodowym związane z zarobkowaniem zmieniają przede wszystkim rolę i miejsce kobiety w rodzinie, a więc następuje tu zmiana stratyfikacyjna. Kobieta staje się finansowo zależna. Jej malejący wpływ na dobrostan ekonomiczny zaczyna przejawiać się - czy to za sprawą przemocy ekonomicznej ze strony partnera, czy za sprawą jej własnej samooceny - w malejącym oddziaływaniu na pozostałe sfery:

(P9, K) Czasami mam ochotę oderwać się od wszystkiego, zrobić coś dla siebie, pojechać do spa, czy nawet przed siebie po prostu. Kupić coś luksusowego. Tak tylko dla siebie. Nie chodzi mi o robienie tajemnicy, to nie o to chodzi. Jakiś skrawek czegoś tylko mojego mieć. Niemożliwe. Raz, że wspólna karta do konta i zobaczy, dwa, że zapyta, czy to było konieczne i przeliczy: kosmetyczka to dwa badania krwi $\mathrm{w}$ klinice.

$(\mathrm{P} 4, \mathrm{~K})(\ldots)$ i muszę gotować to, co dla nas dobre, a nie to co mi smakuje. Zupki chińskie wyszły z menu, chociaż na studiach to była podstawa.

Nawet, jeśli leczenie nie powoduje zmian zawodowych u partnerów i oboje utrzymują swój wkład finansowy w funkcjonowanie związku, to istotnie zmienia się sposób gospodarowania zasobami. Ustalane są nowe, nie zawsze kompromisowe, priorytety wydatków. Ich realizacja wymusza wzajemną kontrolę wzmagając tym samym napięcie i stres:

(P1, M) Szczerze? Niedobrze mi się robi na myśl o łososiu. Jestem normalnym facetem, chcę się napić piwa, zjeść karkówkę z grilla. Z cebulką. I popić piwem. (...) 
Sam się pilnuję, żona nie musi mnie pilnować. Czy wypiłeś tran? Czy biegałeś? Nie za krótko? Nie za długo? Zjadłeś szparagi? Do pracy masz sałatkę. Nie noś telefonu w kieszeni, skarpetki tylko bezuciskowe i inne takie rzeczy. Jak Pani to mówię, to sam słyszę, jak to idiotycznie musi brzmieć.(...) My oboje naprawdę w to wierzymy, każda z tych rzeczy może mieć znaczenie. Ale żona mi jakby... nie ufa, sama musi wszystko sprawdzić, jak dziecku tornister. Czy chipsów nie kupiłem czasem. $(\mathrm{P} 3, \mathrm{~K})$ U nas lekarz mówi, że musimy spuścić trochę ciśnienia i wszystko się ułoży, że przeciwskazań medycznych na razie nie widać. Żeby dbać o siebie, nie nabijać sobie głowy myślami, czyli żeby wyluzować, zająć się swoim życiem. Mówię, żebyśmy pojechali na 2 tygodnie do Egiptu, żeby właśnie się wyluzować, odpocząć i zająć nurkowaniem, w końcu tak się poznaliśmy. A mąż na to, że skoro nie wiadomo, co nam jest, to nie wiadomo, kiedy nam będą pieniądze potrzebne. My jesteśmy krótko po ślubie, nie mamy góry oszczędności, ja go rozumiem. Ale to co, to znaczy, że już na wakacje nie pojedziemy? I obcasów mam tak nie łamać w butach? (...) Zaraz mi się jakaś psychoza wytworzy, że w Sephorze się przez ramię będę oglądać.

W wyniku przeprowadzonych badań można stwierdzić, iż zmiany między partnerami związane ze sferą ekonomiczną przejawiają się w:

1. Dopływie środków utrzymania (zmiana pracy/ zmiana charakteru pracy (praca $\mathrm{z}$ domu), rezygnacja $\mathrm{z}$ pracy (utrata jednego ze źródeł zarobkowania).

2. Przepływie środków - sposobie wydatkowania (ustalane są nowe priorytety).

3. Wzajemnej kontroli finansowej wydatków.

4. Zależności finansowej (częściej partnerki od partnera).

5. Stratyfikacji wewnątrzrodzinnej i ponownego rozdziału ról.

Zmiany w sferze ekonomicznej są katalizatorem zmian także i w innych obszarach. Przykład pary P11 wskazuje jeden z możliwych scenariuszy.

Diagnoza i konieczność leczenia wymusiły rezygnację kobiety z pracy. Utrata niezależności finansowej, brak kontaktu ze znajomymi w pracy połączony z początkowym ukrywaniem niepłodności przed rodziną oraz świadomością nieplanowanej bezdzietności skutkują depresją. Brak środków finansowych na leczenie obu problemów odsuwa na dalszy plan leczenie pierwotnego problemu. Nasila się poczucie niskiej wartości - bez pracy, bez pieniędzy, bez dzieci. Następuje zmiana światopoglądu, zmienia się stosunek do Boga i religii katolickiej, zaczyna się poszukiwanie alternatywnych rozwiązań, co dodatkowo wzmaga konflikty w rodzinie. Psychoterapia zakończona sukcesem pozwala na nowe ujęcie tematu. Kobieta decyduje się na inwestycję w siebie - kończy studia równocześnie podejmując drugie, aplikuje na kilka stanowisk, z czego na stanowisko kierownicze z sukcesem. Konsekwencją jest ponowna redefinicja rela- 
cji między nią a partnerem. Teraz to partner zaczyna mieć obniżoną samoocenę związaną z awansem społecznym i zawodowym żony, zostaje pozbawiony wyłączności w dostarczaniu środków utrzymania, pojawiają się myśli samobójcze wynikające $z$ niemożności zrealizowania tradycyjnie pojmowanych funkcji mężczyzny (ojcostwo, utrzymanie rodziny). Kobieta odzyskuje pewność siebie, w wyniku splotu korzystnych wydarzeń zwraca się ku hinduskiej koncepcji prawa karmy, dzięki czemu staje się otwarta na adopcję oraz działania o charakterze wolontariatu. Nie zaprzestaje starań o posiadanie biologicznego i genetycznego potomstwa, dopuszcza adopcje prenatalne i surogactwo. Mężczyzna trafia na psychoterapię pozwalającą mu zaakceptować nowy porządek rzeczy.

Wydaje się jednak, że najsilniejsze zmiany partnerzy obserwują w relacjach związanych ze sferą cielesności i intymności. Zakres rozumienia pojęcia intymności przez respondentów jest niezwykle trudny do ustalenia, gdyż posługują się nim w sposób intuicyjny. Wydaje się jednak, że jest on bliski rozumieniu zaproponowanemu przez A. Kopffa, według którego „obejmuje ten zakres faktów dotyczących jednostki i jej przeżyć, który w zasadzie nie jest przez nią ujawniony nawet osobom najbliższym, i którego odsłonięcie przed kimkolwiek wywołuje zawsze uczucie wstydu, zakłopotania i udręki” [Kopff 1972: 32-33].

Poza często omawianym zanikiem spontaniczności w życiu seksualnym (seksmisja, seks na rozkaz, „bo jajeczko ucieknie”, „teraz albo nigdy”), zmiany $\mathrm{w}$ podejściu do tych sfer są szczególnie widoczne w medykalizacji ciał i ich deprywatyzacji. Znajduje to odzwierciedlenie w postrzeganiu swoich ciał oraz wypracowywaniu przez partnerów nowego sposobu komunikacji.

Na wstępie należy sobie uświadomić, iż ciało jest konstrukcją społeczną i że to, w jaki sposób postrzegamy siebie w lustrze jest w dużej mierze składową opinii innych o nas samych. „(...) mamy tendencję do tego, aby postrzegać swoje ciała tak, jakbyśmy spoglądali w lustro, którego odbicie uformowane jest przez społeczne opinie i uprzedzenia" [Shilling 2010: 98]. Ze specyfiki leczenia niepłodności wynika charakter relacji społecznych, które wraz z upływem czasu zaczynają ograniczać się do środowiska lekarzy i pielęgniarek pozostając jednocześnie w kręgu rodziny. Ma to determinujący wpływ na sposób, w jaki niepłodni partnerzy zaczynają spostrzegać swoje ciała. „Nowoczesna medycyna bowiem traktuje chorobę jako dysfunkcję organizmu wyrażającą się przez odchylenia w badaniach ambulatoryjnych, diagnostyce obrazowej, czy w postaci konkretnych obrazów klinicznych. Ujęcie biomedyczne prowadzi do traktowania choroby jako patologii (disease), którą można racjonalnie opisać odwołując się do obiektywnych, często jedynie liczbowych, danych" [Kocikowski 2012: 223]. To, co dotyczy ciała zaczyna więc sprowadzać postrzeganie siebie i partnera do poziomu ciała jako narzędzia reprodukcyjnego, możliwego do 
diagnozy i naprawy w oparciu o gromadzone w serwisie dane i zalecenia oraz restrykcje tworzone na ich podstawie.

$(\mathrm{P} 2, \mathrm{~K})$ Nam lekarz powiedział tak: to, że Pana nasienie nie jest najwyższej próby nie znaczy, że Pani może żyć, jak do tej pory. Bo my plemnikom możemy pomóc, a jak Pani w tym czasie na coś zachoruje, to i tak nici z tego będą. To nie był dla mnie problem, to było jakby oczywiste samo przez się ale dziwnie się poczułam, no nie spodziewałam się... inaczej sobie wyobrażałam mój udział. (...) No że będę w ciąży. $(\mathrm{P} 1, \mathrm{~K})$ Niektórzy by powiedzieli, że to tylko 3 lata. Może krótko, ale za to intensywnie. Tyle rzeczy się zmieniło. Tak mówią, że dziecko wszystko zmienia, ustawia na innych torach. U nas też, wszystko praktycznie zmieniliśmy. Wcześniej dużo imprezowaliśmy jeździliśmy na koncerty, eventy. Noc nie przespana to nie był problem. Brak śniadania też nie, i tak przecież było w akademiku. Teraz mamy plan dnia, dietę od dietetyka, treningi wzmacniające, chodzimy na spacery, biegamy, wcześniej kładziemy się spać, nie pijemy alkoholu, staramy się. Ja się już przyzwyczaiłam. Ja zrozumiałam, że tu każda rzecz może być właśnie tą, że kiedyś mi lekarz może powiedzieć: widzi pani, a byłoby dobrze, gdyby pani nie wypiła tego drinka. No chyba bym sobie nie darowała... wiem, że bym sobie nie darowała. Dlatego konsekwentnie tak w to weszłam. (...) Mąż mówi, że nie chce dać się zwariować ale się stosuje w większości.

Kiedy partnerzy uświadomią sobie, że w staraniach o potomstwo stanowią jedność (niezależnie od tego, po czyjej stronie jest faktyczny problem), chęć serwisowania owego narzędzia zaczyna wykraczać poza „ja i moje”, które staje się „my i nasze”.

Do tej pory naszą naczelną zasadą była optymalizacja pracy - czyli zrobić więcej w krótszym czasie. Niestety pracując w takim trybie często zapomina się o śniadaniu, obiedzie, dzienna dawka owoców zastępuję 11 filiżanka kawy...etc. (...) Postanowiliśmy, że nasze zdrowie i spokój staje się teraz najważniejsze. Jeśli chodzi o odżywianie się - zawsze śniadanie i obiad, owoce, dużo wody; jeśli chodzi o tempo - to tylko takie, które nie spina i nie powoduje zbędnego stresu. Łatwo się pisze, trudniej było wdrożyć ale generalnie udało się nam [http://www.4krokidocudu.pl].

Jest to pierwszy moment, w którym ich ciała przestają przynależeć tylko do nich samych i stają się dobrem wspólnym. Taka deprywatyzacja przejawiająca się wzajemną kontrolą i współdecydowaniem jest konsekwencją wyposażania starających się w szereg recept, zaleceń i wskazówek lekarskich.

$(\mathrm{P} 7, \mathrm{~K})$ Jak u mnie..., u nie jest chyba trochę inaczej, bo ja wiem, co mi jest. Ale i tak: nie chodzę na szpilkach, nie noszę ciasnych rzeczy, nie dźwigam, bo po operacjach, bielizna tylko bawełniana. Znaczy na co dzień, bo kiedy mam owulację no to się jakoś staram uatrakcyjnić. Wtedy pozwalam sobie na wino, czerwone. Ale serów już 
nie. Orzechy tak. I winogrona. Staram się być, jak to teraz się popularnie mówi, fit. Teraz fit. Bo parę lat temu po hormonach byłam napuchnięta jak balon. Ale czego się nie robi, tak? I tego samego oczekuję od niego.

$(\mathrm{P} 4, \mathrm{M})$ My dużo rozmawiamy, niczego nie robię bez jej wiedzy. Ale chcę, żeby bardziej dbała o siebie, więcej. Żeby organizm był przygotowany, kiedy dziecko już się zdarzy. No klasyczny przykład, to żeby te zupki chińskie przestała jeść. Wiem, że lubi ale to sama chemia.(...) Staram się ją chronić. No może za dużo tego czasem. Ale rozumie Pani, jak przeziębi nerki, to zaraz zakażenie układu moczowego, antybiotyk i tak dalej. Ja wiem, że nie wszystko przewidzę ale co można, to trzeba.(...) W końcu razem w tym jesteśmy, to razem decydujemy. (...) Ja nie powiedziałbym, że to kontrola. Raczej troska.

Deprywatyzacja ciał partnerów ma także miejsce $\mathrm{w}$ relacjach pomiędzy nimi a personelem medycznym. $Z$ jednej strony odpowiedzialność za to ponosi brak precyzyjnych procedur medycznych nakazujących właściwy sposób traktowania pacjentów, na co $\mathrm{w}$ rozmowach i literaturze wskazują także sami lekarze. Jak pisze Gawande: „W walce $\mathrm{z}$ chorobą naszym punktem wyjścia muszą być nie relacje międzykomórkowe, ale międzyludzkie" [Gawande 2011: 78]. $\mathrm{Z}$ drugiej jednak strony wynika to $\mathrm{z}$ charakteru problemu, który dotyka najbardziej intymnych i wstydliwych dla partnerów kwestii. Siła i zakres ingerencji medycznych, a także ich uciążliwość w połączeniu $\mathrm{z}$ desperacją partnerów powodują, że poddają się oni leczeniu bez troski o własne samopoczucie. Gotowi są poświęcić swoją godność i nietykalność za cenę końcowego efektu, jakim ma być upragnione potomstwo:

Nikogo tam nie interesuje los czy psychika kobiety, która za chwilę ma zajść w ciążę. Siedzenie i czekanie na parapetach i korytarzach, trzymanie nasienia w biuście czy ciągłe szukanie lekarza... [http://www.4krokidocudu.pl].

Każda para decydująca się na leczenie i mająca względną świadomość jego możliwej długotrwałości twierdzi, że jest skłonna do poświęceń, choć nie zawsze ma świadomość ich zakresu. Przykładowo, długotrwałe, uciążliwe i upokarzające terapie łatwiej jest znosić, kiedy ciało jest jedynie narzędziem, a prawdziwy/prawdziwa „ja” to ten w głowie. Jednak wydaje się, że chęć do poświęceń jest odwrotnie proporcjonalna do nadziei na poczęcie: im krótszy staż tym wyższa nadzieja i mniejsza chęć poddawania się ostatecznym rozwiązaniomprzy czym pojęcie „ostatecznego rozwiązania” jest przez badanych rozumiane różnorako: dla jednych jest to zapłodnienie pozaustrojowe IVF, dla innych surogactwo oraz adopcje prenatalne i adopcje społeczne. Niektóre pary chcąc uniknąć uciążliwego leczenia i ponoszenia wydatków od razu decydują się na zapłodnienia in vitro, inne czekają z tym do końca. Ponadto, skłonność do po- 
święceń przyjmuje wykres sinusoidalny, zależny od etapu radzenia sobie z chorobą - na początku choroby jest dość niska (negacja, bunt, gniew), rośnie na etapie negocjacji i pertraktacji, by znów zmaleć w fazie akceptacji.

Na przykład trzydziestoletnia autorka blogu pisze:

Poprawę komórek jajowych mam uzyskać dzięki suplementacji końską dawką DHEA przez 60 dni. Potem prędko na kolejne IVF i po sprawie. Doskonale wiem jak działa DHEA. Dodatkowy testosteron w krwioobiegu spowoduje, że mój dość przyzwoicie podleczony trądzik stanie się moim stanem permanentnym. Nigdy się na to nie zgodzę i nikt mnie nie przekona, że będę szczęśliwą mamą z mordą jak muchomor. Jestem mega-przeczulona na tym punkcie, ponieważ ten defekt zabrał mi resztki radości życia $\mathrm{w}$ ostatnich miesiącach [http://mychcemymiecdziecko. blogspot.com].

Dla porównania, po 5 latach starań $(\mathrm{P} 6, \mathrm{~K})$ stwierdza:

(...) Bo jeśli ktoś mi powie, że mi da $80 \%$ szans, nawet $75 \%$ - nie musi być 100 , ale da mi wielką szansę, to, powiem brzydko, niech mi tam grzebie ile chce.

Z kolei autorka historii nadesłanej w ramach kampanii „Powiedzieć i Rozmawiać" po wielu operacjach, dwukrotnych nieudanych adopcjach komórek jajowych i poronieniu adoptowanych prenatalnie bliźniaczych zarodków w 21 tygodniu ciąży pisze:

W 21 tygodniu ciąży trafiłam do szpitala. Wyrok - pęcherz płodowy w pochwie. Potem nie do końca pamiętam co się działo... Poród.... Pierwszy urodził się chłopiec, żył 30 minut. Druga urodziła się dziewczynka. Położna położyła mi ją na brzuchu, a ona strasznie płakała, do tej pory mam ten dźwięk w uszach... Żyła 20 minut.

Potem pogrzeb i wszystkie te durne formalności, ZUS, ubezpieczenie bla bla bla. Pakałam przez 2 tygodnie non stop. Aż zabrakło łez... Ale nie chce się poddawać. To jest mój jedyny cel w życiu, jeśli nie będę mogła do niego dążyć to nie będę miała po co żyć... Teraz czekam na wizytę u lekarza i zaczynamy wszystko od nowa.. Adopcja prenatalna to jedyne co mi zostało [http://www.nasz-bocian.pl].

Przeniesienie prawa własności nie ogranicza się wyłącznie do ciała - partnerzy zaczynają także ingerować w swoje życie emocjonalne i psychiczne starając się kontrolować wszelkie te jego aspekty, które mogły by negatywnie wpłynąć na poczęcie. Wśród nich możemy zauważyć brak zgody na oglądanie drastycznych filmów, czytanie nieodpowiedniej literatury, słuchanie zbyt głośnej i pobudzającej muzyki (zamiast na przykład muzyki relaksacyjnej), negatywne myśli, czy spotkania z niewłaściwymi osobami: 
(P8, K) Kiedy mamy moment silnego starania, to nie jeździmy do teściów. Teściowa jest upierdliwa, gdera, narzeka... Ogólnie złą atmosferę wprowadza, może Pani zapomnieć o relaksie na łonie natury.

(P5, M) Generalnie lubię wszystkie jej koleżanki. Tylko po prostu nie wiem, czy spotykanie się na babyshowerach jest jej akurat najbardziej potrzebne. Zawsze jest po tym przygnębiona, co chyba oczywiste. Więc jej mówię, żeby może nie chodziła.

Teza o powszechnej medykalizacji społeczeństwa należy do kanonu socjologii medycyny. Ten tak zwany imperializm medyczny pozwala medycynie na uzyskanie monopolu definiowania problemów zdrowotnych i zarządzanie nimi obligując pacjentów do określonego sposobu postępowania, co ukazano powyżej. Obejmuje też sferę pojęciową, gdy język i definicje medyczne stosuje się do mówienia o danym problemie [Domaradzki 2010: 464-473].

(P4,M): Jak coś Pani powiem, to Pani zblednie. Nie było mnie jakiś czas, służbowo wyjechałem na półtora tygodnia, a ona w tym czasie miała dwie wizyty i dużo siedziała w internecie. Jak wróciłem, to mi mówi: Najpierw HSG bo trzeba by odetkać jajowody. Zapytałem: co? A ona dalej, bez mrugnięcia okiem, że potem juji [ IUIintrauterine insemination, domaciczna inseminacja nasieniem partnera - dop. M.T.], tylko na naturalnym cyklu, bo od klo [clostilbegyt, hormonalny lek stymulujący owulację - dop. M.T.] się mogą torbiele zrobić. Zbaraniałem. Teraz jakby Pani chciała, to mogę Pani cały wykład zrobić. (...) często tak rozmawiamy. A jak inaczej? Jak trzeba przetkać jajowody, to trzeba przetkać jajowody, inaczej tego Pani nie powie przecież. (...) nie, no nie od początku. Przecież nie siedzieliśmy przy stole i nie rozmawialiśmy o nasieniowodach, prąciach i endometrium. Trochę czasu upłynęło, jakoś się dokształciliśmy i już wiemy o czym mówimy. No łatwo nie było. Jak Pani sobie wyobraża, że kino, kolacja, wino a później co, że kochanie, moje jajowody nie przyjmą dziś twoich plemników? Ma Pani pojęcie, jak trudno takie coś przez gardło przecisnąć? Niech Pani spróbuje mężowi powiedzieć przy kolacji, że ma Pani hemoroidy i te żyłki w tyłku Panią bardzo bolą przy stolcu. Potrafi Pani?”

Podobne - w mniejszym lub większym stopniu - opinie przedstawiali wszyscy respondenci. Dla każdego z nich drogą zrozumienia przyczyn niepłodności były intensywne kursy medyczne realizowane za pośrednictwem fachowych publikacji, czytelnictwa forów internetowych i podczas rozmów z personelem medycznym. Jednakże zrozumienie problemu i ujęcie go w sposób medyczny, choć pomocne w komunikacji z lekarzami, nie zawsze jest możliwe w komunikacji w związku. Jest to oczywiście także wynikiem poprzednich doświadczeń, jak kultura, wychowanie, a przejawia się w swoistym dualizmie językowym. Rozumienie problemu odbywa się na poziomie medycznym i z zastosowaniem terminologii medycznej, ale mówienie o nim z partnerem odbywa się za pomocą języka pozwalającego na łatwiejszą komunikację. Rozmowy partnerów 
o niepłodności muszą być szczere, aby leczenie było skuteczne, co nie czyni ich łatwiejszymi. Dla osób dorastających w przekonaniu, że intymność, cielesność i seksualność są rzeczami wstydliwymi, o których się nie rozmawia, rozmowy te są szczególnie trudne. Medykalizacja języka wcale ich nie ułatwia, bo pozwala jedynie informować o aspektach medycznych pomijając sferę emocjonalną, która i tak jest trudną w werbalizacji (co ciekawe, fakt ten jest uznawany za zaletę w komunikacji z innymi - lekarzami, rodziną, czy pracodawcami, bo stwarza barierę ochronną. Inną typową barierą ochronną jest zaprzeczanie przed innymi swoim problemom i staraniom, głównie ze wstydu i/lub niechęci do przyznania się do słabości:

Kiedyś o tym napiszę książkę... Kiedyś - czyli jak się nam już uda. Jak nie - zachowam to w tajemnicy do końca życia. Wstydzę się niepłodności (...). Czemu ukrywamy ten fakt? Bo się wstydzimy, bo czujemy się gorsi i upokorzeni, bo przeżywamy kryzys kobiecości i męskości, bo staliśmy się socjopatami. Aaaa z resztą można wyliczać..." [http://mychcemymiecdziecko.blogspot.com].

Dlatego partnerzy, na swój własny użytek, wypracowują własny język, tworzą nowe pojęcia lub nadają nowe znaczenia już istniejącym. Ten sposób pozwala jednocześnie na w miarę bezbolesne przekraczanie granic własnej intymności, jak również jest mechanizmem ułatwiającym oswojenie się z problemem i zaakceptowanie go. Spersonalizowanie elementów i procesów składających się na leczenie niepłodności czyni to leczenie bardziej „uczłowieczonym” (P10, M) - wroga (przyczynę) można zlokalizować, nazwać, walczyć z nim lub z nim negocjować.

(P10, M) Najpierw w ogóle nie wiedzieliśmy, jak rozmawiać. To znaczy wiedzieliśmy, że musimy tylko nie wiedzieliśmy jak. Nie da się tak, nawet chociaż znaliśmy się przecież długo, no nie da się tak zacząć mówić o takich intymnych sprawach, jak na przykład masturbacja. U lekarzy też nie było lepiej, siedzimy na drugiej, czy trzeciej wizycie z wynikami, a lekarz pyta żony, jaki kolor ma śluz i jak pachnie, no czy śmierdzi, żona zbaraniała, a ja zzieleniałem. Dzisiaj przyjąłbym to normalnie pewnie. Z czasem się nauczyliśmy tych wszystkich terminów i chyba po prostu zobojętnieliśmy. A jak już wsiąkliśmy w leczenie, w szpitale, w historie na korytarzach, to zaczęliśmy mówić językiem zaawansowanym. (...) I wtedy te rozmowy jakieś łatwiejsze są, takie... przyjemniejsze. (...) jakiś przykład... Noo, podczas seksu lepiej mi się myśli dalej chłopaki, do boju, kto pierwszy ten lepszy, żołnierze do ataku, niż jakbym miał myśleć najsilniejszy plemniku, zapłodnij komórkę jajową mojej żony.

(P10, K) Potwierdzam, że nadaję imiona (śmiech). U mnie problem jest $\mathrm{z}$ endometrium. Mówię na nie Endecja (śmiech). Że jeśli jej zależy na narodzie polskim, to niech pozwoli mi się rozmnażać. Czasem tak sobie rozmawiamy. 
Rozmowy z badanymi, analiza forów internetowych i zaangażowanie użytkowników pozwoliły na stworzenie podstawowego słownika wyrażeń najczęściej używanych przez osoby walczące z niepłodnością:

- @, małpa - krwawienie miesięczne

- 2w1 - kobieta w ciąży

- Antyki - tabletki antykoncepcyjne

- Beta, Becia, Beatka, Betka - test krwi wykrywający stężenie hormonu ciążowego beta hcg,

- Bromek - Bromergon

- CLO - clostilbegyt - cytrynian klomifenu

- Dc - dzień cyklu

- Dpo - dni po owulacji

- Dupek - duphaston

- Endo - endometrium (błona śluzowa wyściełająca macicę)

- ET, E.T. (czyt. Iti) - embriontransfer; przeniesienie zarodków do macicy (ok $48 \mathrm{~h}$ po zapłodnieniu pozaustrojowym)

- Fasolka, groszek (zarodek o określonej płci)

- Gin - ginekolog

- HSG- Histerosalpingografia, ocena drożności jajowodów z kontrastem

- II (dwie krechy) - pozytywny wynik testu ciążowego

- ISCI - dokomórkowa mikroinjekcja plemnika

- IUI - inseminacja

- IVF (4f) - zapłodnienie in vitro (in vitro fertilization)

- Laparo - zabieg chirurgiczny wykonany metodą laparoskopii (bez otwierania powłok)

- Lutka, Lusia - luteina

- Monit - miesieczna ocena owulacji w usg.

- Owu, ovu - owulacja

- $\mathrm{PCO}(\mathrm{S})$ - zespół policystycznych jajników

- PCT - test po stosunku, test postkoitalny

- PRL - prolaktyna

- Prl po mtc; Prl po mecie (lub po mietku) prolaktyna po obciazeniu metaclopramidem.

- Przytulanko (stosunek płciowy)

- Spermo - spermogram

- Śnieżynki, mrożaczki - zamrożone embriony

- Tc - tydzień ciąży

- Żołnierzyki (armia plemniorów) - plemniki 
Infantylizacja języka nie oznacza, że problem, do którego się odnosi, jest niepoważny. Ten swoisty slang, czy język branżowy nie ma również na celu podkreślenia ekskluzywności, bo nikt $\mathrm{z}$ tego kręgu wtajemniczonych nie znalazł się tam $\mathrm{z}$ własnej woli, ani nie powoduje, że uczestnicy czują się wyjątkowi. Za jego pomocą partnerzy próbują redefiniować swoje relacje i priorytety, akceptować rozwiązania dotychczas nierozważane. Pomaga im przechodzić kryzysy tożsamości, kryzysy wiary, kryzysy związku. W wielu wypadkach zbliża partnerów do siebie, przez co łatwiej im zaadaptować się do zmian, jakie w ich życiu wymusza niepłodność. Zmiany te to nie tylko spadek jakości pożycia seksualnego i refundacja zabiegów in vitro, co najczęściej pojawia się w publicznym dyskursie. Zmiany te dotyczą bowiem każdej sfery życia wskazując na złożoność problemu i jego społeczne oraz indywidualne konsekwencje.

To prawda, że wszystko jest możliwe i że marzenia się spełniają - ale niestety przedłużające się w czasie starania mają negatywny wpływ na tyle płaszczyzn życia, emocje, praca, sex, związek, że naprawdę nie ma sensu w nieskończoność tego przedłużać. Szkoda życia. Nie mielibyśmy odwagi, aby to wszystko opisywać czy układać jakieś tezy o 4 krokach, gdybyśmy nie byli mocno przekonani, iż ten końcowy sukces jakim jest dziecko, to nie tylko osoba Naszego Doktora, ale także My - nasza wiara, nasze wątpliwości, nasze przeczucia, nasz plan, nasze poszukiwania i w końcu, nasza akceptacja kolejnych etapów, jako kroków do zostania rodzicem [http://www.4krokidocudu.pl].

Brak potomstwa to nie tylko konsekwencje dla przyrostu naturalnego, polityki emerytalnej czy systemu podatkowego. Za pojęciem „niepłodność" kryją się bowiem indywidualne życiorysy, których pogłębiona analiza może przyczynić się do lepszego zrozumienia problemu i jego wpływu na instytucję rodziny, jej członków oraz na całe społeczeństwo.

\section{Bibliografia}

Bidzan M. (2010), Niepłodność w ujęciu bio-psycho-społecznym, Kraków

Conrad P. (1992), Medicalization and social control, "Annual Review of Sociology" t. 18

Domaradzki J. (2012), Polityka płci: „Słaba płeć, medycyna i kontrola społeczna, „Nowiny Lekarskie" nr 79

Gawande A. (2011), Lepiej, Kraków

Gąsiorowska M. (2005), Zagrożona męskość, „Żyjmy Dłużej, Raport - Niepłodność”, numer specjalny 1

Goffman E. (2005), Piętno. Rozważania o zranionej tożsamości, Gdańsk 
Illich I. (2002), Limits of medicine. Medical Nemesis: the expro-priation of health, New York Kocikowski M. (2012), W poszukiwaniu cudownego uzdrowienia. Studium przypadku $z$ antropologii ciała i medycyny, [w:] K. Konarska (red.), Ciało cielesne, Colloquia Anthropologica Et Communicativa t.4, Wrocław

Kopff A. (1972), Koncepcja praw do intymności i do prywatności życia osobistego. Zagadnienia konstrukcyjne, „Studia Cywilistyczne” t. XX, Warszawa, Kraków 2012, nr 20

Kozioł K., Lewandowski P., Wolski J. K. (2000), Rozród człowieka. Malejąca rola kobiety w niepłodności małżeńskiej, „Nowa Medycyna” nr 5

Kübler-Ross E. (1998), Rozmowy o śmierci i umieraniu, Poznań

Pawelec B., Pabian W. (2012), Niepłodność, Pomoc medyczna i psychologiczna, Sopot

Przybył I. (2005), Wpływ bezdzietności na stosunki małżeńskie, „Ruch Prawniczy, Ekonomiczny i Socjologiczny", R. LXIV, z. 3, nr 3

Shilling Ch. (2010), Socjologia ciała, Warszawa

\section{Źródła internetowe}

http://www.4krokidocudu.pl/historia1.html [30.08.2013]

http://mychcemymiecdziecko.blogspot.com/ [5.09.2013]

Niewiadomska A., Najczęstsze przyczyny niepłodności, http://www.medigo.pl/ciaza-i-dzieckonieplodnosc/najczestsze-przyczyny-nieplodnosci/page/0/25

Szamatowicz J., Niepłodność idiopatyczna, http://www.rodzinko.pl/niep-odno-ae/5137-niepodno-ae-idiopatyczna.html

Wysocki G., Niepłodność to wielki dramat pary. Rozmowa z Bodą Pawelec i Wojciechem Pabianem, http://ksiazki.wp.pl/tytul,Nieplodnosc-to-wielki-dramat-pary-z-psychoterapeutka-Bogda-Pawelec-i-ginekologiem-Wojciechem-Pabianem-rozmawia-GrzegorzWysocki,wid,19939,wywiad.html?ticaid=111362 [30.08.2013]

„Raport Podstawowe informacje o rozwoju demograficznym Polski do 2012 roku GUS 2013” http://www.stat.gov.pl/cps/rde/xbcr/gus/L_podst_inf_o_rozwoju_dem_pl_do_2012.pdf 


\section{SUMMARY}

\section{When Ovu Is Still Not Coming, Little Soldiers Are Lazy, Beta Is Low, And a Dream About a Baby Bean Is Only a Dream... The Impact of Infertility on Partners' Relationship}

Unplanned childlessness or inability to give birth again are nowadays a serious social problem - different statistics say there are from 1 to 3 million pairs impacted. Childlessness is not only an inability to have children but the entire scope of factors affecting social everyday life. It influences financial, professional and interpersonal relations situation but, above all, it changes intrafamilial relations. Harsh and long-lasting therapies require redefining relations between partners and crossing many barriers - intimacy (in both purely physical and illness related sense), strength (physical and emotional) or trust. It forces couples/ marriages to redefine their relations - build new rules of family (and social) life devoted (or not) to a common (or not) goal. Partners' bodies no longer belong to them and start being treated as a tool necessary for reproduction. They way of "using" the body changes, the way one sees one's changes - there is a separation between the mind and the body which is subject of therapies, the new language allowing partners to talk about the body and its parts is created (the language that eases familiarizing with the problem) - often childish, e.g. snowflake $=$ frozen embryo, soldiers $=$ sperm). The goal of the article is to outline everyday life problems that couples/marriages face when trying to have children for a very long time. Previous, media driven approach to the topic reduces it to political discussions about in vitro without mentioning mental, social and existential fear that accompanies infertile couples and changes their relationships. The topic is illustrated by the preliminary results of quality research carried out in 2010 on couples struggling with infertility.

\section{Keywords:}

infertility, childlessness, in vitro 